
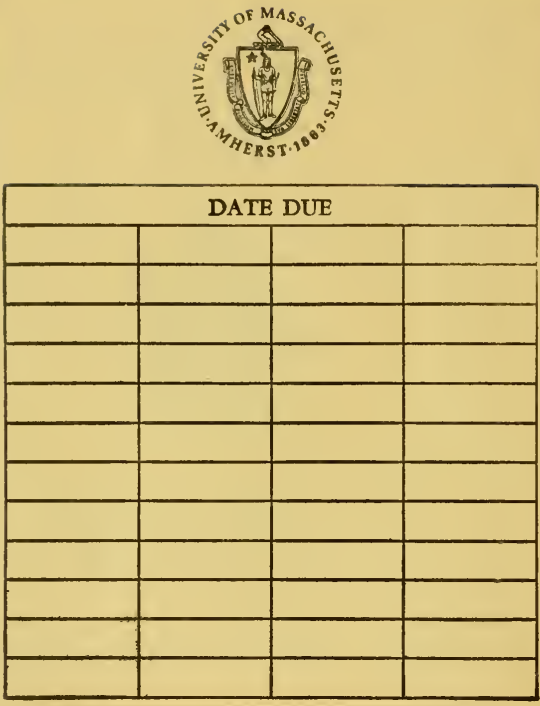

UNIVERSITY OF MASSACHUSETTS LIBRARY

$\begin{array}{ll}\text { SF } & \text { CARD } \\ 375 & \\ \text { G75 } & \end{array}$



nownengen 




\section{History of Sheep Husbandry in Massachusetts.}

\section{LECTURE BY}

HON. JAMES S. GRINNELL OF GREENFIELD.

Delivered at the Public Winter Meeting of the Massaciusetts State Board of Agkiculture, at Boston, DECEMBER 2, 1891.

With Accompanying Discussion.

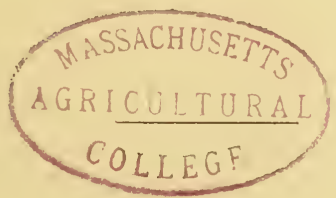

BOSTON :

WRIGHT \& POTTER PRINTING CO., STATE PRINTERS, 18 Post Office Square. 


$$
\begin{array}{r}
136.3 \\
988
\end{array}
$$




\title{
HISTORY OF. SHEEP HUSBANDRY IN MASSACHUSETTS.
}

\author{
BY HON. JAMES S. GRINNELL OF GREENFIELD.
}

The subject of sheep husbandry, always one of the greatest importance to the whole farming community, seems again to be exciting general interest and attention in our State, and, in the opinion of the Board of Agriculture, would be aided and advanced by a somewhat extended consideration in a paper which I was directed to prepare and bring before this meeting, and by the full discussion which is to follow.

In all ages the sheep has been a prominent representative of rural husbandry, protitable and eminently respectable, from the time that Abel, the first keeper of sheep, made to the Lord an acceptable offering of the firstlings of his flock - early lambs; and many hundreds of year's later that great farmer and flock-master, Job, reckoned among his stock fiviteen thousand sheep.

Originally neither the flesh of the sheep nor of any other animal was used as an article of food. According to Biblical history, only a vegetalole diet was permitted, - the firuit of every tree in the garden of Eden (with one exception) "and every herb of the field;" so that for about sixteen hundred years, till after the deluge, no sheep were killed to be eaten. It was only after Noah harl stepped forth from the ark and offered his salcrifice that the Divine permission was given, "Every moving thing that liveth shall be meat for you ; even as the green herb have I given you all things." From this time on the flesh of the sheep was not only an acceptable offering to the Almighty, but as an article of food is frequently mentioned in Holy Writ, from the dressing of a single lamb in very early days down to the magnificence of Solomon, who, besides his estahlished character for wistom generally, manifested an exceeding good taste 
and consideration for his household by having a hundred sheep slanghtered for their daily maintenance and enjoyment. Sheep probably found their way into Europe hy the Hellespont with the early civilization of its inhahitants, and after a long interval into Italy ; they were early cultivated in spain, having probahly been introduced there from Africa long before the founding of Rome. The more northern part of Europe was a great forest, unfavorable to the growing of sheep, and their numbers seem always to have been small. The Celtic tribes paid more regard to the ox than to the sheep, and the flocks of the early inhalitants of Europe never equalled those of the Syrian and other Asiatic shepherds.

As the sheep of this country (except the Merinos) mostly atme from England, it would be curious and interesting to trace their introduction to that country. Unfortmately this is shrouded in the darkness which envelops the British Islands prior to their invasion and conquest ly the Romans. During that dynasty, however, wool was spun and woven and woollen fahries were made in Britain; and in course of time the woollens of Winchester, which were said to rival the spider's weh in fineness, attained the highest reputation, and maintained it for centuries; lut there is no record of the sheep from whose fleece these were spun and woren. It is helieved that the Hibernians had from the Phonicians accpured the art of spinning and wearing long before the invasion of the Romans upon England, and while the people of the larger island were still clad in the skins of wild animals, and of oxen and sheep, after their untraceable introduction. From that time to the improvement of sheep and the settlement of this country is a long interval. Either the sheep were not very early introduced here, or the chroniclers of that day did not see fit to make any special mention of them; horses, cattle, and, strangely, goats, are much earlier and oftener noticed than sheep.

In 1629) permission was given to ship from Sonthampton one hundred and forty eattle, horses, sheep and goats; how many were landed, if any, does not appear. July, 1631, from Barnstable in Devonshire were shipped eight heifers, at calf and five sheep. June 15,1633 , thirty-four 
Dutch sheep were landed, forty having been lost at sea. In the same year these or others are recorded as having been carried onto an island in Boston harlior as a place of protection against wolves. In 1635 eighty-eight Dutch ewes were brought in, valued at fifty shillings each. July, 1633 , an order was made that no sheep should be exported. May 14, 1648, the following order was made by the General Court: "that forasmuch as the keeping of sheep tends to the good and henefit of the country, if they were carefully preserved, henceforth it shall be lawful for any man to keep sheep on any common, accounting five sheep to one great beast. And if any dog shall kill any sheep, the owner shall either hang his dog forthwith, or pay double damages for the sheep. And if any dog has been known to course or bite any sheep before, not being set on, and his owner had notice thereof, then he shall both hang his dog and pay for the sheep."

In 1634 an order was passed hy the court: "that whereas, the country was in great straits in respect of clothing, and the most likeliest way tending to supply in that respect is the raising and keeping of sheep within our jurisdiction, it is therefore ordered and enacted by this court, that after the publication hereof no person or persons whatsoever shall transport any ewes or ewe lambs out of this jurisdiction to any foreign place or port, upon the penalty of the forfeiture of five pounds for every ewe or ewe lamb so transported."

In 1652 Charlestown had as many as four hundred sheep; and in 1658 John Josselyn wrote, in the account of his two voyages to the Colonies, of there heing eight hundred at Black Point in this State, and again mentions their having great store of sheep in the colony.

Twenty years later, Sir Edward Randolph, commissioner of the Crown, wrote in his official correspondence that "New England ahounded in sheep." By successive inportations, care in breeding and preserving, forbidding exportattions and the killing of sheep ats much as possible, they multiplied greatly, they became abundant on the commons, and were watched and guarded by a shepherd. Herding, now so successfully practised by the most eminent sheep grower in the State, wis first used in this country in Rowley, where 
permission was granted to erect sheep gates, or lengths of movable fence to be set 11 ) at night as protection against wolves and dogs.

\section{Clothing.}

Next to foor and shelter, the great exigency of the early settles's was of comse clothing sufficient not only to cover their nakedness, but to keep them wam in this cold climate. In this respect, as in some others, they were content to receive from the customs of their habaroms neighbors suggestions which were not withont nse to them in their peculiar ciremetances. The original clothing of the Indians was from the furs and skins of wild animals. Much skill was evinced in the dressing of buffalo, deer, elk and other skins for that purpose; for external wear they were prepared with the hair or wool on, and for under garments the smaller skins were made into a kind of " chamois" leather lyy removing the harr and dressing them with the brains of the animal, which rendered them very soft and pliable. A sequaw would thus prepare eight or ten skins in a day. Morton says the Indians "made their skins into very good leather, making them 'plume' and soft; the moose skins they commonly dress bare and make them wondrous white; the moecasins and leggings were usmally made firom the moose skins." The colonists made much use of these materials, which comported well with their moged mode of life and the severity of the climate. Indeed, they were not maecustomed to the use of similar materials in their native comtry ; for in England, even in that day, leather dressed as buff and in other styles, and worn as doulblets, hreeches or vestr, formed no inconsiderable part of the elothing of some clakses, and for some purposes was worn by the nobility. These solore and frugal materials continued in use till after the era of independence, and gaments wholly or in part of buckskin or other leather could be found in the wardrolos of even the wealthy men of that day. Deerskins dressed were then worth fiom three shillings and sixpence to seven shillings eath.

In 1747, Joseph Calef, a leather dresiorer of Charlestown, was robbed hy hureglars, who took a variety of sheepskins dressed for clothing, some cloth colored for breeches very 
much upon the red, other's were cloth colored thin skins for gloves. In the "Boston Evening Post," Feluruary, 1748, are advertised "two fulling mills for the fulling of leather."

As fast as the settler's could produce the materials and provide the men and means, they had spun and woren for clothing flax of their own growing, the cultivation of which they had commenced early; cotton from Barbadoes, and wool imported from Malaga and some other ports. All these textile goods for more than a hundred years were spun and woven and dyed in the homestead; every house had a spinning-wheel, and every other house a loom. The price of spinning worsted or linen we are told was usually two shillings per pound; for knitting coarse yarn stockings, half a crown a pair; for weaving linen half a yard wide, ten to twelve pence per yard. The cost of manufacturing eighteen pounds of wool into twenty yards of cloth was $\$ 21.24$, or $\$ 1.06$ pèr yard three-quarters wide. In the earlier days rery little cloth was on sale, it was largely consumed in the family or used in barter with the neighbors for other necessities; and almost the only attainable way of getting at a price is to read some dead man's inventory. In 1671 worsted was worth sixty-six pence per pound, and woollen thirty-two pence. Much linsey-woolsey was made for men's wear, of linen warp and wool filling, valued at eighteen cents per yard. Homespun garments or cloth were seldom inventoried; a piece of homespun is valued at three and sixpence in 1681 , justifying a statement of a letter writer of that day, that in 1675 "there is no cloth made worth four shillings and no. linen over two shillings and sixpence per yard;" perhaps not, but it covered a race unsurpassed for loravery and fortitude. I might perhaps truthfully say that they were men of great understanding, for among the outfits provided for the colony in 1629 , "a great store of shoes is ordered of neats leather of sizes firom ten to thirteen."

Domestic manufactures began early, especially spinning and weaving; for in 1639 bome-made cloth is found in Peter Branch's inventory, and appears in increasing quantities, though probably insufficient to keep pace with the increasing population, for in 1640 a bounty was offered for home-made cloth. In 1656, finding the supply still short, 
the selectmen were ordered to assess on each fimily the spinning and weaving of a certain amount of cloth. This eloth was woven on hand looms, as was all the eloth of every kind made in England as well as here; for it must be rememhered that the power loom was not in existence, - it was invented hy Rer. Edward Cartwright in 1788, and perfected loy him in 1790 .

The first fulling mill for dressing this home-made cloth was built at Rowley in 1643 hy a company of weavers, skilled workmen from Yorkshire, under the spiritual and business charge of Rev. Ezekiel Rogers, where the first woolen cloth was dressed in New England. Another fulling mill was erected in Salem about the same time, and soon atter they hecame common. The price of this home-made cloth was six or eight shillings per yard, imported eloth fifteen to eighteen shillings.

In 16.57 the value of a sheep was one pound, an ox five pounds, horse ten pounds, eow three pounds, wool eight pence, negro boy twenty pounds. A story which I came across in preparing this paper, though not entirely pertinent, will not be displeasing to you, as illustrating some of the. trials of this arly colonial life. In the latter half of the last century lived a small fimily on a stony firm in Connecticut. The stock consisted of a dozen sheep and a cow, who, besides her yield of milk, added her services on the plough; corn bread, milk and hean porridge were the stiples of their dict. The father heing incapacitated by long illness, the mother did her work in the house and helped the boys in the fields. Once in mid-winter one of the boys needed a new suit, and there was neither money nor wool in the house. The mother sheared the half-grown fleece firom a sheep, and in a week it was made into clothes for the boy. The shorn sheep, so generous in such need, was protected from the cold hy a wapping made of hraided straw. They lived four miles from the meeting-house, to which the mother and her hoys walked every sunday. Those hoys hecame the Rer. Samuel Nott, a fimous preacher, and Rev. 1)r. Eliphalet Nott, the President of Union College.

Our ancestors emigrated from different places in the United Kingdom, and some from the various countries of 
Europe; they brought with them domestic animals and then implements of huslandry to sulbdue and cultivate the wilderness. Each, as would be natural to suppose, made choice of the favorite breed of his own immediate district to transport to the new world, and the admixture of these hreeds formed the mongrel family known as native sheep; anid the perils of war and the incursions of wild beasts of prey these were preserved with attentive care. The descendants of these sheep, known in our day as " native" in distinction from the breeds of recent known importation, were of two types,one with white faces and the other with dark or spotted faces and legs. These last were known in the Connecticut valley and through the western part of the State as "English runts" or "Irish smuts," and were undoubtedly taken from the counties lying on the south coast of England, Devon, Hampshire and Sussex, and were the same stock of sheep from the Downs of Sussex and Hampshire, that in later years, under the care and skill of John Ellman, Jonas Webb and others, became the matchless "South Downs."

A very convincing proof of this occurred in my own experience. Some thirty years ago or more, when Mr. Fay imported the Oxford Downs, I had from him a large superior ram which I coupled with fifty of the Irish smut ewes picked up for me by a friendly drover in the western part of Franklin County and southern Vermont. The product was marvellous; I had succeeded in obtaining what horse men would call a perfect " nick." The type of the lambs, sereral of which were twins, was entirely changed from that of the ewes, and seemed to assume the character of the improved South Down in the Oxford Down ram; shortened the neck, colored the faces uniformly brown, widened the breast, shortened the legs, put on more wool, sprung out the ribs, deepened and broadened the hind quarters, and gave them a weight of seventy-five pounds in ninety days. So I believe the old South Down blood was in our " native" sheep, and only needed developing.

The larger white-faced, long-legged, bare-legged, lightfleeced sheep of the country were originally brought in considerable numbers from the Texel and other parts of Holland. These common sheep gave a wool only suited 
for coarser falbrics, yielding in the hands of good farmers a fleece of not over three and one-half or four pounds. They were slow in arriving at maturity, compared with the present improved English breeds, and yielded when full grown only from twelve to fourteen pounds per quarter of a middling quality of mutton which, howerer, was in but slight demand; they were usually long-legged, light in the fore quarter, and narrow on the hack and hind quarter. They wcre hardy, easy keepers and good hreeders, often rearing, almost entirely destitute of care and shelter, one hundred per cent of lambs, and in small flocks with more care a still larger proportion; these were dropped in Mareh and April. Restless in their disposition, their impatience of restraint almost equalled that of the untamed sheep of the Rocky Mountains; and in many parts of the country it was common to see flocks of from twenty to fifty roaming with little regard to enclosures orer the possessions of the owner and his neighbors, learing a portion of their wool on erery thorn and bush.

I do not purpose to give a history of the different breeds of sheep cultivated in England, but briefly to notice those that have receired the preference of our own farmers.

\section{South Downs.}

Seventy-five years ago there were in the United Kingdom of Great Britain twenty different so-called breeds of sheep, each peculiar to the county or circumscribed district in which they were bred, and many of them probahly not breeds in the strict sense of that term, as capable of reproducing their own type under all eircumstances. Nany of these have heen absorbed, and are disappearing by eross-breeding with the more profitable breeds ; of these, the one having undoubtedly the most influence has been the South Down, which has stamped its characteristics on the popular families of the Oxford, the Hampshire and the Shropshire Downs, now, with the exception of some Merinos, almost exclusively bred in this state.

The chalk hills called downs, running through the county of Sussex and into Hampshire on the sonth coast of England, are the home of the South Downs, now so famous all orer 
the world, not only for themselves, but as fixing their characteristics on every breed upon which they have been crossed; and this they owe to the prepotency of their blood, conducted down unmixed for nearly a thousand years.

But the South Downs were not always what they are now; a little more than a hundred years ago an enterprising sheep owner, Mr. John Ellman, commenced the improvement of the South Downs by selecting judiciously and breeding most carefully. This was afterward continued with equal skill by Mr. Jonas Webb, who with others has brought these beautiful animals to their present perfect condition; their pleasant brown faces, their broad, straight backs, their deep briskets and splendid legs of mutton are everywhere known. For this part of the country they and their congeners, the Shrops, the Hampshire and the Oxford, are the most raluable and popular sheep we have.

\section{Hampshire Downs.}

From the South Downs, bred on the old white-faced horned sheep of Hampshire and Wiltshire, came the grand Hampshire Down; but the strong blood of the South Down has done away with the horns, and given them its own dark face. They are large, heavy sheep, producing splendid hardy lambs, with a good fleece and an admirable leg of mutton; and they, as well as all the Downs, impart their characteristics wherever used.

\section{Shropshires.}

The Shropshires were produced by breeding the South Downs on the small, dark-faced horned sheep of Shropshire on the border of Wales; the size was improved by a cross or two of Leicester, and reverting to the South Downs, who have taken off the horns, and made them one of the most popular breeds in England and in this State, bearing all the excellent characteristics of the Downs.

\section{Oxford Downs.}

The Oxford Downs were large and white-faced; but under the influence of the South Downs and the Hampshire Downs, and with an occasional dip into the Cotswolds to add to and 
keep up the size (which has been done with all these breeds improved by the influence of South Down blood), they have become grand sheep with a good fleece, heavier than the Cotswold and somewhat finer; they are very likely to drop twins, and are very capable of raising them. All of these Down sheep are worthy of our attention and care.

\section{Leicesters.}

The original Leicesters were large, coarse, inferior animals, till Robert Bakewell, something over a century ago, commenced their improvement; and by care, selection and breeding steadily for one purpose, he made them the best mutton sheep in the world at that time, not caring whether they had any wool or not. He bred them so close and so fine as greatly to impair their constitution. They are not suited to our climate and general treatment as pure-bred animals, but our native sheep were years ago improved by a cross of Leicester for size.

\section{Cotswolds.}

The Cotswolds came from the county of Gloucester, early noted for wool production; its sheep were so highly prized that four hundred years ago a number were exported to Spain by royal permission. They are remarkable for size and symmetry, and are of an imposing presence. The head is large, without horns, carried high and well wooled, with a large forelock hanging over the face; the face and legs are white, occasionally slightly mottled with gray or dark brown; the wool is long, wavy and lustrous, sometimes measuring eight to ten inches, and commands a high price; the quality of the flesh, - though not equal to the Downs, their great size and good shape make them desirable especially to cross on other breeds when increased size is desired, and they have been used for that purpose in this State.

\section{Dorsets.}

Another breed which is attracting considerable attention in this country at the present time, and has long been popular in England, is the Dorset. From time immemorial these sheep have been naturalized in the county of Dorset, and fornerly extended over a large tract of country. 
These sheep possess small horns eommon to both male and female ; they have white faces, and legs which are somewhat long but fine, showing a very good breast and a fine leg of mutton with loins broad and deep; wethers will fatten to twenty pounds to the quarter. They are a hardy race of sheep, docile, and capable of subsisting on scanty pastures; their mutton is good, and they shear six or seven pounds of close wool, finer than the Downs.

The property of the Dorsets which remarkably distinguishes them is the fecundity of the females, and their readiness to receive the ram at any season. This, and their capacity for yielding an abundant supply of milk, render's them particularly desirable for raising early lambs. In England they have been largely and profitably used for raising lambs for winter use even as early as Christmas, and called "house lambs," for which in London there is a great demand. The lambs are hardy, thrifty, mature early, and will dress twenty-eight to thirty pounds at sixty or seventy days old. Probably a cross of a South Down ram on Dorset ewes would give more size and early maturity with the superior nursing quality of the dam. They tend strongly to twins, sometimes having triplets, and their full flow of milk suffices to raise the lambs. Some sheep farmer's think one lamb for a ewe is better than two; but if the ewe is a good milker, and well fed, twins are profitable. $\mathrm{Mr}$. Youatt says, "If a farmer has feed enough and good enough, twins are highly desirable." An old English couplet, written before the first sheep was landed in Plymouth colony, says :-

"Ewes yearly by twinning rich masters do make;

The lambs of such twinners for breeders go take."

\section{Merinos.}

The breed of sheep, however, which in its production of fine wool has been the most important in the history of the world, is the Spanish Merino. Long hefore the Christian era the finest garments worn by the nobility and wealthy citizens of imperial Rome were woven from the fine wools of Truditania, Andalusia and Estramadura in Spain. Subsequently the original Spanish sheep were raised and improved by the Moors, who brought with them into Spain fine sheep 
from North Afriea, which they had carefully cultivated, and from whose fleeces were woven fabrics of superlative quality.

The fine sheep of Spain a hundred years ago numbered over twenty millions, and were long preserved as a monopoly with jealous care. Sweden has the honor of being the first country which secured a flock of these coreted animals. France, though adjoining Spain, obtained none till near the close of the last century. In 1765 the Elector of Saxony succeeded in securing a flock, which, crossed on the native fine sheep of his kingdom, and carefully bred, made the Saxonies so famous for the fineness of their wool here sixty year's ago. The skill and ability with which the Spanish Merinos were bred and cultivated in this part of the country were convincingly shown at an international exhibition in 1861 , at Hamburg, Germany, when American Merinos, lored by George Campbell of V'ermont, and exhibited under the direction of Col. Daniel Needham, formerly of our Board, captured the prizes and defied competition.

\section{Saxonies.}

The Saxonies were first imported by Samuel Henshaw of Boston, and much was anticipated from the introduction of these sheep producing such superlatively fine wool. When they were introdnced, in 1823 or 1824 , they were much smaller and of a feebler constitution than their parent stock, the Spanish Merinos; the wool was from an inch to an inch and a half long on the back and sides, and a washed fleece weighed only about one and three-fourths pounds. Attempts at improvement by crossing with the Merinos were made in vain; both deteriorated, and before 1850 the Saxonies had mostly gone out. They have been lessening in number greatly ever since, and, although we nominally have about a thousand, I doubt if there is a genuine, pure-bred Saxon in the State.

From the long-established policy of the British Gorernment in encouraging and fostering the manufactures of that country and of discouraging and even forbidding any attempts toward it in her colonies, we found ourselves, at the close of the war of the revolution, not only without the manufactories of woollens, but also destitute of the material from 
which to make such fine goods as were necessary. The attention of our statesmen was early directed to supply this deficiency, and they wisely looked to the Merinos of Spain to accomplish it; but it was with the greatest difficulty that the Spanish Government could be persuaded to allow any of them to be exported.

The first important importation of these was made by Col. David Humphreys of Connecticut, then United States Minister to Spain, who brought a flock of about one hundred to his farm in Derby, Connecticut. These increased to such an extent that he made at his mill in 1807 several hundred yards of fine cloth. In 1809 President Madison was indueted into office in the first inaugural suit of Ameriean broadcloth, the coat from Colonel Humphrey's flock, the waisteoat and small clothes from the flock of Mr. Livingston of New York. Arthur Scholfield wove the first piece of fine broadcloth that was ever made in this country from Merino wool, at Pittsfield in this State.

The most important early importation, however, was by Mr. William Jarvis, American consul at Lisbon in Portugal, who seized an opportunity to buy some of the finest sheep in Spain, the confiscated property of some wealthy nobleman, and sent to this State and to different parts of the country about thirty-eight hundred fine Merinos, the most and finest ever exported. These and others, distributed over all the States bordering on the Atlantic coast, soon changed the character of the wool and wool growing of the country.

It is not strange that we of Massachusetts should have taken the lead in this industry of wool growing and wool manufacturing as we did in every mattcr advancing the material or the intellectual progress of civilization. The first sheep producing the desired quality of wool for making fine cloth were either landed on our shores or brought directly within our borders, where they were eared for and multiplied amazingly. There were then no IVestern States; Ohio, which has since assumed the lead in sheep raising and in sheep legislation, had just received her baptismal nomination; all the sheep, all the implements of manufacture, such as they were, all the men of character and industry, were this side the Alleghanies. 
The men who planted themselves on the coast of Massachusetts liay came not only for religious freedom but to speedily build themselves homes with sueh necessaries and comforts as they enjoyed in the homes they had left behind them, by laboring at the same oceupations at which they had wrought in England. The list of trades and those who worked in them would astonish one, from glass workers to needle maker's; the names of Joseph Jenks, John Pearson, Edward Giblon. Israel Stoughton and others who started manufactures should be kept in perpetual remembrance.

Our climate is admirably adapted to sheep growing, one proof of which is that in 110 country are sheep so little liable to diseatse ats in New England. Our rough hills corered with sweet herhage from which all superfluous water disappear's about as fast as it falls, and our sharp, dry winds, are naturally adapted to the wants and conditions of sheep, which always thrive best in the purest and most bracing atmosphere. Wet seasons and wet soils are destruetive to sheep. The New England flock master is forced to recognize what the English sheep raisers were long in learning, - the economy and benefit of shelter in winter, even in their less rigoron climate. The truth is that sheep in New England, if well sheltered and furnished with proper food, will produce better wool and mutton and a larger increase of lambs than sheep exposed, even in the genial climate of Virginia. Sheep are most indiscriminate feeders, and delight in a change of food. One who takes the pains to obscrve them when feeding will be surprised at the eontinual shifting they make from one speeies of herlage to another, and upon our hills and valleys there is to be found the full variety which their nature rerquires.

The first mill for weaving and finishing fine cloth was at Pittsfiels, run by Arthur Scholfield, a wearer from Yorkshire, who settled here and made the first lroadcloth, fine enough for any gentleman's wear at that time. Sereral hundred yards of homespun were annually dressed at Rowleyand Salem. That there was abundant woot of common kind widely distributed is shown by this fact, among others, that in the first years of this century two thonsand pairs of handknit stockings were annually exported from the Island of Martha's Vineyard. 
On the 15th of November I addressed circulars containing a few interrogatories to various men in the State whose names were given me as sheep raisers, to the number of about a hundred. I have been much gratified at the full replies made, of which I have received over sixty, for which I beg to thank very heartily the senders. I intend if possible to tabulate the results, and to have them presented to the public at some future time.

The great decline of our sheep and wool commenced apparently about fifty years ago. In 1838 we had 384,614 sheep, of which 200,383 were Merinos, 46,985 were Saxonies, and 137,246 other breeds. In 1888, fifty years later, we had 51,539 sheep, of which 4,500 were Merinos, 1,000 were Saxonies, and about 46,000 other breeds. In 1838 the total value of sheep and wool was $\$ 1,116,608$; in 1888 it was $\$ 295,000$. Thus it will be seen that in fifty years our sheep have decreased in numbers over 333,000, and our wool $\$ 12,000$ pounds. While our losses in aggregate numbers have been very large, yet the gain in individual animals shows our great improvement in breeding.

In 1838 each sheep was valued at $\$ 1.50$, and sheared two and three-fourths pounds to the fleece. Fat lambs were valued at $\$ 1.75$ each. In 1888 each sheep was worth $\$ 5.00$, and sheared four and one-half pounds of wool, and lambs were worth $\$ 5.00$ each. So that men who own sheep now hold a property worth more than ever before.

The following table shows the diminution of the sheep generally, and by breeds, which, with any adequate causes to account for it, I have faithfully pondered over in a spirit of unintelligent curiosity :-

\begin{tabular}{|c|c|c|c|c|c|c|c|c|}
\hline & \multicolumn{4}{|c|}{ YEARS. } & Saxonies. & Merinos. & Other Breeds. & Total. \\
\hline $18 \pm 5,$. & . & . & • & . & 33,875 & 165,428 & 155,640 & 354,943 \\
\hline $1855,$. & . & . & • & . & 6,800 & 65,584 & 72,825 & 145,215 \\
\hline $1865,$. & - & - & • & . & 3,126 & 55,428 & 110,888 & 169,442 \\
\hline $1875,$. & . & - & . & . & 1,631 & 14,456 & 42,686 & 58,773 \\
\hline 1885,. & . & . & $\cdot$ & - & 1,215 & 5,307 & 48,618 & 55,140 \\
\hline
\end{tabular}


In 1890 the whole number by the assessors' returns was 45,899 ; the breeds are not given. Since 1865 the decrease has been gradual every year, and almost invariahle. What was the cause or what were the causes that produced this unprecedented decline in an industry pleasant and profitable?

\section{Decrease in Number of Sheep.}

Those who know nothing of the sulject confidently assert some one reason; those who have studied the matter don't pretend to know, but suppose that all the causes assigned may, combined, have produced the effect for which no one alone can be regarded adequate. Among the causes assigned are the operation and the fluctuation of the tariff; the greatly increased importation of wool from Australia, New Zealand, South Ameriea and other foreign eountries; the introduction of shoddy (invented in 1803) to a large extent some years later; the enormously increased importation, by enlarged railway faeilities, of sheep and lambs fiom the West; the great increase of the dairy industry in milk, cream and butter; the destruction of sheep by dogs; the diminution of flocks induced by the decay of fences. The first three of these alleged causes for the decrease of our flocks apply, especially to loss in the past, while the last four show reasons which act against the revival of this industry. I pass lightly over these, as, in the talk which will follow this paper, these alleged causes will be more fully and satisfactorily considered, and this will form the most valuable part of this meeting.

\section{Impritation of Sheep from the West.}

One of the most important eauses for the decrease of our own home-grown sheep for the slaughter for mutton and lamb has been the great influx of these animals from the West, from Canada and from other States, for killing and not for breeding nor the production of wool, induced by the vastly increased railway facilities showing a large adrance in the demand for mutton and lamb in our markets.

At Brighton, on the week before Christmas, 1839, two Franklin County men held four hundred sheep, erery one in the market; yet, so ample was that supply and so inactive 
the demand, that they could not raise the market a half cent a pound, and finally sold with difficulty. Just twenty years after that, Christmas week, 1859, five thousand four hundred sheep changed hands from the drover to the butcher. On the week preceding Christmas, 1889, fifty year's from the first date, the receipts were $\$ 10,444$, and the demand such as called for advanced rates, and a quarter of a cent per pound was easily realized. This increase has continued anumally. In 1890 the number of live sheep discharged at Brighton and Watertown was 583,545 , of which the Western were 370,067, from Canada 88,313, sheep of Massachusetts 6,181, from Rhode Island and Connecticut 48 head. A very few of these are sold for breeding, some for export, but almost all are slaughtered at the market.

The reports of animals every week (for which I am indebted to Mr. Whitaker of the "New England Farmer") show receipts varying in numbers from 5,000 in March to 17,722 in September and October. This indicates a very enlarged demand for a most nutritious, cheap and wholesome article of food, shown by theoretical considerations, as well as by careful experiment, to be quite equal to beef and superior to pork or almost any of the meats we use.

\section{Dairy Industry.}

Probably the great interest at the present time and for some years past in the making of milk, cream, butter and cheese, with a paying price and quick returns for the product, has had much to do in repressing the keeping of sheep and raising lambs, aggravated by the uncertainty of that branch of farm industry through destruction by dogs. The growth of the dairy production has been as remarkable as the decrease of sheep products. As a matter for comparison, I give the dairy products of 1865 , the first year that a complete census was attempted for them, with the last, of 1885 :-

1865.

Milk

Butter, 


\section{5.}

Milk,

Butter, including creamery, .

Cheese, including factory,

Cream,

\section{5.}

$\$ 10,312,762$

$2,611,351$

99,478

202,706

$\$ 13,226,297$

The cows and heifers of 1865 numbered,

174,386

The cows and heifers of 1885 numbered,

198,997

\section{Fences.}

I have no doubt that imperfect fencing had a considerable part in discouraging farmers who were keeping sheep. Many fences, only enough of which are left to make division lines, were built long years ago. The life of a Virginia rail fence is about sixty years; to a stone wall there is no limit of duration, but there is to its ability to turn sheep. A rail fence becomes at last broken and rotten in spots, and must be repaired, sometimes by lopping down a small tree, sometimes by putting in a rotten rail or a couple of insufficient stakes. The stone wall, always a "balance wall," has been rudely laid a hundred years more or less by the unskilled hands of the farmer and his hired man; year after year it has settled, and the top stones have tumbled down, especially on a side hill, aided by long years of storm and by careless hunters and boys. Where the stones have fallen so as to make a set of convenient steps, the sheep will cheerfully walk over, or will erawl through any hole or gap in a fence. Early in the spring the farmer, annoyed at the continual excursions of his sheep the preceding season, starts out with his boys to mend his fences; a long, cold, wearisome joh it is, and usually done in the most slouching and perfunctory manner. A few years of this, and he begins to agree with the boys that cows are easier kept.

Recently barbed wire has come to our relief, and a single strand stretched on posts or stakes above the top of the wall makes it pretty secure, while a fence of four or fire strands is cheap, will restrain the sheep, and protect them from dogs.

\section{Tariff.}

Tariff is a dreadful-sounding word, and canses as much dismay and terror now as it did when borne by that pirat cal old Arab cut-throat Tarif Ibn malek al-ma-feri, who, taking 
possession of a small island at the straits of Gibraltar, more than twelve hundred years ago, levied a compulsory tribute, from all who came his way sailing in or out of the Mediterranean, and who gave his name to a system of exaction which has continued to this day. What influence this Arabborn institution may have had on the increase or the diminution of sheep and wool of this State, I don't know, and haven't been able to find out by a system of careful reading and inquiry. Twenty-five or thirty years ago it was a common complaint from old farmers who had flocks of hundreds of Merinos and Saxonies that their wool growing was ruined by the tariff, and that they had to abandon sheep raising. My opinion is that, for the past thirty years at least, the effect of any legislation would be very immaterial, considering the small quantity and low grade of our wool, in reducing to any large extent the number of our sheep so terribly depleted; but I leave this to be settled in the discussion to follow.

\section{Dogs and Sheep.}

Beyond all question the real reason which deters farmers from engaging in the raising and breeding of sheep at the present time is the constant apprehension of the destruction of flocks and their demoralization by dogs. Our observation and the statements of sheep growers generally throughout the Commonwealth universally show this. We are often asked by dog owners why there is so much complaint now, when there was but little fifty or sixty years ago. The answer is that in numbers the dogs and the sheep are out of all proportion to what they were then. Then, when there were three hundred and forty thousand sheep, with but few dogs, and the sheep in flocks of hundreds, and each sheep worth only a dollar and a half, if a half-dozen sheep were killed they might not be missed, and, if they were, the damage was inconsiderable; but now, when a man bas a flock of say forty, each worth six dollars, and often bearing lambs, ravages by dogs, killing a half or a third of his flock, tearing others and demoralizing all, become a very serious matter. I shall not go into any detail of the losses we have had, nor shall I attempt to stir up agitation. of no use; dogs and dog owners have the mastery, and a double-barreled shot gun with eleven buckshot, or a few 
grains of strychnine placed in a beef's head judiciously located as a preventive against loss (by foxes), are our only guards. To show how unavailing any attempt at legislation must be, it is enough to give some figures.

The census shows 15,218 dogs, valued by their 13,071 owners at $\$ 10.35$ each. So much for dog owners and census returns when they make such returns as suit themselves. The county treasurer's books show the tax paid on dogs to be, for $1890, \$ 169,057$. The tax is $\$ 2.00$ per head for males, and $\$ 5.00$ for females. The number of dogs has not been returned to the comptroller, but, as he says, the number of female dogs being small, you can allow $\$ 3,000$ for them; dividing the rest of the tax by two gives you 88,000 dogs and about as many dog owners, as against 45,899 sheep and 2,500 owners. It's a pitiable sight : 2,500 men contending for the right to enjoy a peaceable, legitimate and profitable industry, against 88,000 holders of generally dangerous, savage and worthless non-producing brutes.

\section{Sheep as Food.}

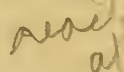

Mutton and lamb are favorite food of the English and Scotch of all classes; notwithstanding all that has been said or written of the "roast beef of Old England," more mutton is eaten by people of every rank than beef. Mutton formerly was not a farorite food of the people of the United States, though the proportional consumption is greatly increasing; the difference may be largely attributed to circumstances which have led to habit, and habit to a large extent regulates the appetite. The eircumstances may be partly these : that formerly we had none of the real mutton sheep to eat; our old native stock was poor, and the Merinos vastly worse. The sheep formerly killed were too often old and poor, and the cheapness of the animals too often brought them as food to those who were compelled to eat them; farm laborers, apprentices, servants and others learned to thoroughly dislike mutton; and many men and women so far advanced as to have perhaps every other recollection of school days wiped from the memory, still retain in the most lively manner the disgust ereated by the inevitable daily mutton of the boarding-house. The remarkable experiments 
of Dr. Beaumont, conducted more than fifty years ago, are authority to this day. He found that lamb and mutton were more digestible than any other meats we are in the habit of consuming, were assimilated more readily to the system, and consequently are more nutritious.

While mutton is regarded by medical men and physiologists as the most nutritious meat, it is also the most economical to purchase at the usual prices. English chemists and philosophers, by a series of careful experiments, find that 100 pounds of beef in boiling lose $26 \frac{1}{2}$ pounds, in roasting 32 pounds, and in baking 30 pounds, by evaporation and loss of soluble matter, juices, water and fat. Mutton lost by boiling 21 pounds and by roasting 24 pounds; or, in another form of statement, a leg of mutton costing raw 15 cents would cost boiled and prepared for the table $18 \frac{1}{2}$ cents per pound. Boiled fiesh beef would at the same price cost $19 \frac{1}{2}$ cents per pound; sirloin of beef raw, at $16 \frac{1}{2}$ cents, costs roasted 24 cents; while a leg of mutton at 15 cents would cost roasted only 22 cents. These facts have been long known and demonstrated, and it is to be much desired that our people should appreciate them and apply them to daily use. The taste for and consumption of mutton will increase according to the quantity and quality of the production. Mr. Mechi, the celebrated farmer and scientist, said he was convinced that beef must sell twenty per cent higher than mutton to make it pay.

In this connection it is pertinent to recall the statement previously made before this Board by one of its most prominent members, of the necessity, in slaughtering sheep and lambs, to remove immediately the paunch and intestines before skinning. If allowed to remain in only a few minutes, they will impart a strong, disagreeable "sheep taste." Probably ignorance and a disregard of this important fact are largely responsible for the disgust in which the flesh of mutton and lamb was formerly held.

The keeping of sheep requires constant care and is full of solicitude, but it is profitable, and, as farming goes among the occupations of men, it is pleasant. This is the commercial and prosaic view; but there is an incident in our history connected with this, poetical and solemn. In 
this late scason of the year, and at the approach to Christmas Day, we cannot dissever the thoughts of this industry from this occasion. It cammot be foreign to our minds, nor is it unworthy of us as Christian men, to remember and note that the first announcement of the birth of the Sariour of the world was made, not to the scientific astrologers who made the hearens their study, not to the learned scribes and Pharisees who pondered the law and the prophets, and not to those who lived in kings' houses elothed in fine raiment; but it was to shepherds who watched their flocks by night on the star-lighted plains of Judea, followed by the sublimest solo and chorus that ever fell on mortal ears, of "Glory to God in the highest, on earth peace and good-will toward men."

The Charrusx. Gentlemen, I know I voice your opinion when, as chairman for the day, I thank Mr. Grinnell for his most charming and instructive paper. Mr. Hollis of Boston has kindly come here to give us some figures relative to the amount of mutton that is consumed in Massachusetts. IVe all know that there is an immense amount of mutton and lamb consumed here which has been imported into this State. We have plenty of land, and all we want is a little ambition among farmers to become shepherds, and we can raise a large percentage, if not all, of the mutton and lamb that is needed in Massachusetts. Will Mr. Hollis kindly give us a few figures?

Mr. Holls. I arrived in town this morning a few minutes hefore I came up here, and I am not prepared to give any figures.

The Chammax. In a general way can you not say about how many carcasses you slaughter or your company slaughters?

Mr. Hollis. Well, I happen to have in my pocket a little paper on which I have kept a memorandum of the number of sheep we have slaughtered since 1885 . In 1885 we slaughtered 376,415 ; in $1886,367,822$; in $1887,399,272$; in $1888,387,345$; in $1889,396,124$; in $1890,414,620$. In the ten months of this year, up to the first of November, we slaughtered 357,484 . 
The Chamman. Thank you very much. That shows, gentlemen, that the demand for mutton is not on the decrease. Will Mr. Hollis kindly tell us ahout what price mutton has averaged for the last eight or ten months?

Mr. Hollis. I do not think that I could. It varies from month to month.

The Champman. But for good fair mutton you usually get from 5 to 6 cents a pound for the carcass dressed, do you not?

Mr. Hollis. I think it will vary from 6 to 10 cents a pound, and lambs from 6 to $12 \frac{1}{2}$ cents.

Mr. Grinnell. What proportion of the carcasses are exported from Boston?

Mr. Hollis. There has not been any exported for the last two or three year's. I do not think there is any mutton exported from the United States now.

Mr. Gminxell. Then of course all the sheep that come into the Brighton and Watertown markets are slaughtered there?

Mr. Hollis. Yes, sir.

Mr. Grinvell. Is there any reason for the variation in the amounts in one year and another?

Mr. HoLlis. That is owing to the supply and demand. There is no particular reason for it, that I know of.

Governor Hosnd. I would like to ask the gentleman from what territory those sheep are mostly obtained?

Mr. Hollis. You might say from Halifax down to Virginial. From the first of June until the first of Septemher we get our supply from Kentucky, Tennessee and Virginia.

Governor Hosnd. Have you noticed any particular improvement in the mutton character of the sheep you have received during this year?

Mr. Hollis. From some sections there is, others not.

Governor Hoard. From what sections do you find an improvement?

Mr. Hollis. From some parts of the West and some sections in Canada.

Governor HoArd. I mean, of course, in the eating quality.

Mr. Hollis. Yes, sir; we see quite an improvement in the sheep coming from Virginia and Tennessee. 
Governor Hoard. Do you attribute it to improved breeding?

Mr. Hollas. Yes, sir.

The Cunmux. Well, gentlemen, we have learned that there is a demand for mutton, and we want to learn how to raise it, and we want to know how to keep out troublesome and dangerous intruders. Mr. Sessions, I think, is mepared to talk a little about fencing.

Secretary Sessioxs. Mr. Chairman, I am of the opinion that the proposition adranced by the lecturer that the fence question has had considerable influence in the decadence of sheep keeping in Massachusetts is correct. As I go among farmers and talk alout the sheep industry they reply to me, "We eamnot keep them anywhere; it will cost so much to fence them in or fenee them out that it is a nuisance; and without fences we do not know where we shall find then in the morning or in the evening." Now, this is a serious problem, as the lecturer has pointed out. The fences in the more rural and farming districts of the state are of the character which he has noted, - the old Virginia rail fence and stone wall; and every one who has had experience with sheep knows that a stone wall is of very little use, unless it is a very expensive wall, built perpendicular on the side towards the sheep. Ind then, again, the old Virginia fence that wals a good fence when it was first built, hecomes old and dilapidated and costs a great deal for repairs; and when you have got to refence a pasture or make repairs to any great extent, the cost will be enough to deter a beginner from undertaking to raise sheep).

Now, the sisatyist also alluded to a new material for fencing, - hathed wire. There is in the minds of some people, many people, perhaps, a prejudice against harhed wire, hecause of its lialoility to injure any animal; hut my own experience teaches me that that objection does not apply to sheep. I have fenced sheep for years with harbed wire, and I never knew a sheep to be injured by it. Occasionally a sheep will he caught by it, and perhaps a trifle of wool will be pulled off, but the waste and suffering that comes to the sheep from that camse is trifling. 
Now, of course the question of fencing in sheep with any kind of fence depends upon its eost and its adaptability to the end in view; and with us I think the question of cost is really the one to be consiclered, for it is perfectly patent to every man that barbed-wire fence can be so constructed as to turn sheep. There is another point about this barbedwire fence which does not apply to a fence of any other material, and that is, that it can he made so as to turn dogs. I think it is perfectly feasible to eonstruct a fence that will turn dogs; and the cheapness of the material as now furnished ly the manufacturer is such that the cost of a fence that will not only turn sheep but protect them from dogs is comparatively small. I have some figures which I have collated from information olstained from different parties; and, having applied to them my own experience, ohservation and judgment, I helieve the estimates are reliable considering the circumstances under which they are made. Of course, in making an estimate of the possible or the probable cost of a certain kind of fence, the estimate must be made upon some definite set of cireumstances; and it is only safe to predicate upon the most favorable circumstances, because the amount of obstacles to be overcome will vary in different circumstances and under the different conditions of different farmers, and that must he calculated by the individual himself, he only knowing what the obstacles are. I refer to the cost of digging post-holes, the cost of overcoming the difficulty of uneven ground, getting through bushes, and all that sort of thing. These figures were based largely upon a statement of the cost of eighty rods of six-wire fence built about two years ago by Mr. Henry Green of Hadley, Mass. He says there has not been a single dog in the pasture since the fence was finished. The four lower wires are placed nearer together than the two upper ones. The fence is four feet high and the posts one rod apart, which is sufficient to support a barbed-wire fence. The wire cost 4 cents per rod; the staples 1 cent per rod; the posts cost 7 cents each. Mr. Green says that two men can set the posts and string the wire for twenty-five rods in a day. The cost of labor per day is say $\$ 1.50$ per man, or at the rate of 12 eents per rod. So we have as the cost per rod: six strands of 
larbed wire, at 4 cents, 24 cents; staples, 1 cent; one post, 7 eents; labor setting posts and stringing wire, 12 cents. Total, 44 cents. This, remember, is a dog-proof as well ats a sheep-proof fence.

I have also received, at my request, a price-list from the Washburn \& Moen Manuficturing C'ompany, Worcester, which gives the cost of first-quality galvanized Giliden barbed wire at 4 cents per pound, and they state that it weighs one pound per rod, and their discount for cash will cover the freight. So that Mr. Green's estimate of 4 cents per rod is borne out by the price-list of the largest manufacturing establishment of the kind in the state.

I have also a statement from Prof. Wr. P. Brooks of the Massachusetts Agrieultural College that one man set the posts (one rod apart) and strung the wire for sixty rods of five-strand wire fence on the college farm in less than two days. This proves that the lahor estimate in the first instance is a firir one.

These statements correspond with my own experience. They are for work done where the soil is not stony or underlaid with hard-pan. Allowance must of comrse be made for such obstacles.

From the foregoing I calculate that it will cost to fence at square lot of ten acres (one hundred and sixty rods) with six wires and posts $\$ 70.40$, or, per acre, $\$ 7.04$. I am satisfied that five wires ean be so arranged as to be a dog-proof fence as well as a sheep-proof fence; and therefore I have made a calculation of the cost of a five-wire fence, which amounts to $\$ 62.40$ for a square lot of ten acres, or $\$ 6.24$ per acre. As you all know, the larger the field the less the distance around it. I have on that account made calculations for several sizes. To fence a sfpuare lot of twenty acres (two hundred and twenty-six rods), six wires, with posts, $\$ 99.44$, or a cost per acre of $\$ 4.97$; with five wires and posts, $\$ 88.14$, or a cost per acre of $\$ 4.41$.

But there is another set of conditions on many of our pastures, especially upon the hills in the restern part of the State and upon the pine plains of that section, where the pastures have been neglected and considerable timber has started, and where a line of trees will be found along the line 
of the proposed fence, so that in many instances posts can be dispensed with by stringing the wire on trees. Of course the trees would not be at regular distances in all cases; but by having posts every six, eight, or even ten rods, the intervening supports can he made of stakes which can be driven, with the help of a bar to make the holes, at a comparatively tritling cost, and the material can be gotten from the trees as you go along. I have therefore made a calculation here, leaving out the posts and the cost of setting the posts, so that persons having pastures situated in the way I have described may reduce the necessary cost of fencing rery considerably. My calculations are as follows :-

To fence a square lot of 20 acres, six wires (226 rods), posts, $\$ 99.44$

Cost per acre

With five wires and posts, .

88.14

Cost per acre,

To fence a square lot of 20 acres, six wires, where trees take the place of posts, cliscounting cost of posts and one-half cost of labor, .

Cost per acre,

With five wires on trees,

With five wires on trees, per acre,

To fence a square lot of 30 acres (277 rods), posts, six wires, .

To fence a square lot of 30 acres (277 rods), posts, five wires, .

Cost per acre, six wires,

108.03

Cost per acre, five wires,

To fence a square lot of 30 acres, without posts (trees), six wires,

To fence a square lot of 30 acres, without posts (trees), five wires,

Cost per acre, six wires,

Cost per acre, five wires,

To fence a square lot of 50 acres (358 rorls), posts, six wires,

To fence a square lot of 50 acres (358 rods), posts, five wires,

Cost per acre, six wires,

Cost per acre, five wires,

To fence a square lot of 50 acres, without posts (trees), six wires,

To fence a square lot of 50 acres, withont posts (trees), five wires,

Cost per acre, six wires,

Cost per acre, five wires,

$\$ 157.52$

139.62

3.15

2.79

110.98

93.08

2.22

1.86

To fence a square lot of 75 acres ( 437 rods), posts, six wires, $\$ 192.28$

To fence a square lot of 75 acres ( 437 rods), posts, five wires, 
Cost per acre, six wires, . . . . . . . . . $\$ 2.56$

Cost per acre, five wires, . . . . . . . . 2.27

To fence a square lot of 75 acres, withont posts (trees), six wires, . . . . . . . . . .

To fence a square lot of 75 acres, without posts (trees), five wires,

Cost per acre, six wires, . . . . . . . .

Cost per acre, five wires, . . . . . . . . . . 1.51

To fence a square lot of 100 acres (50:3 rods), posts, six wires,

To fence a square lot of 100 acres (503 rods), posts, five wires,

Cost per aere, six wires,

$\$ 221.32$

196.17

2.21

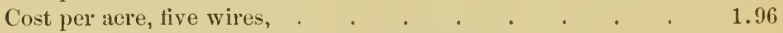

To fence a square lot of 100 acres, without posts (trees), six wires,

To fence a square lot of 100 acres, without posts (trees), five wires,

Cost per acre, six wires,

Cost per aere, five wires,

155.93

130.78

1.31

To fence a square lot of 200 acres (716 rods), posts, six wires,

To fence a square lot of 200 acres (716 rods), posts, five wires,

$\$ 315.04$

279.24

Cost per acre, six wires, . . . . . . . . . . . 1.57

Cost per acre, fire wires, . . . . . . . . . . . 1.39

To fence a syuare lot of 200 acres, withont posts (trees), six wires,

To fence a square lot of 200 acres, without posts (trees), five wires,

Cost per acre, six wires,

Cost per acre, five wires,

221.96

186.16

1.11

To fenee a square lot of 500 acres (1,131 rods), posts. six wires,

To fence a square lot of 500 acres (1,131 rods), posts, five wires,

Cost per acre, six wires,

4.97 .64

441.09

Cost per acre, five wires, . . . . . . . .

To fence a square lot of 500 aeres, without posts (trees), six wires,

To fence a square lot of 500 acres, without posts (trees), five wires,

Cost per acre, six wires,

Cost per acre, five wires,

350.61

294.06

To fence a square lot of 1,000 acres (1,600 rots), posts, six wires,

To fence a syuare lot of 1,000 acres (1,600 rods), posts, five wires,

Cost per acre, six wires,

Cost per acre, five wires, . . . . . . .

To fence a square lot of 1,000 acres, without posts (trees), six wires, 
To fence a square lot of 1,000 acres, without posts (trees) five wires,

Cost per acre, six wires,

Cost per acre, five wires,

So you see it does not take a fortune to fence a large lot. And this, remember, is a dog-proof fence as well as a sheepproof fence.

The Chairinan. Well, gentlemen, we have not only found that we ean afford to raise sheep in Massachnsetts, but we have found out by aetual figures that it is cheaper to build a dog-proof fence than it is to lay up a stone wall.

Mr. Grinnell. Does anybody know the cost of a board fence built of hoards say six inches wide, four on a post?

The Chairmax. Mr. Horton, will you kindly tell us the expense of a board fence?

Mr. Hortov. It is very easy to get at the expense of such a fence as that. The hoards for a four-hoard fence with us cost on an average about $\$ 16$ per thousand feet, which would be $\$ 1.60$ for a hundred feet of fence. It takes double the number of posts that it does for a wire fence, and the posts require to be better posts than for a wire fence. Under ordinary circumstances a hoard and post fence four feet high would cost something over a dollar a rod, - from $\$ 1.06$ to $\$ 1.10$, using good material. Figuring it upon that basis, it would cost about three times what it would to make a wire fence.

The C'marrman. And, instead of keeping dogs out, it invites them to jump through. Gentlemen, we want to cover the ground of sheep husbandry as earefully as we can, and I will call on Mr. J. D. Avery of Buckland, who has been a practical and successful shepherd for a good many years.

J. D. Avery. Mr. Chairman, some few weeks ago I received a line from the essayist suggesting that I make a comparison between dairying and sheep growing. I attempted to do this, but have not succeeded, for the reason that the dairymen were not prepared to give me figures showing their receipts and expenses. I have figures from three sheep farmers, showing their receipts, and in one instance the writer gives me his expenses, and it may be interesting to you to hear those figures read.

The first flock to which I will call your attention consisted 
of 21 breding ewes in the year 1890 . They were fed upon rowen hay twice a day during the winter till the first of March; after that they were fod oftener, and a daily ration of grain was added, consisting of lom four quarts, oats four quarts, and corn two quarts. They were turned to pasture May 1. The reeeipts that year were as follows:-

28 lambs, average weight Angust 1, 91 pounds, sold at $6 \frac{1}{2}$ eents per pound,

168 pounds wool, at 22 eents,

$\$ 165.62$

36.96

Total, .

$\$ 202.58$

which is very nearly $\$ 10$ per head. This gentleman gave me no figmres of the expense except the grain, which amounted to only $\$$ ! for the 21 sheep.

Question. Where were those sheep kept?

Mr. Avery. This flock was in the town of Shellume.

Question. What was the hreed of sheep?

Mr. Avery. A high-grade sonth Down. I have known this gentleman's flock for the last ten or fifteen years, and he has used nothing but the very best of pure-lned south Down sires. He has paid on an arerage probahly sas for those rams, used them two years, then ehanged them to prevent in-breeding, and he has ieplenished his flock by keeping the best of the lambs. I figure those lambs as all sold at $6 \frac{1}{2}$ cents per pound; he did not sell them all, lout of eomrse it is perfectly fair to figure them at that price. He reserved tive of the best of the lambs, which avraged 100 pounds apiece.

Question. At what age?

Mr. Arenr. They were dropped in March, and they were sold the first of August. Something like five months, perhaps. He has improved his flock in that way, by using the best pure-bred sires and selecting the best of the lambs. Now, these lambs would have hrought him $6 \frac{1}{2}$ cents a pound per head if he had sold them, and most of us would probably have thought that was too much of a temptation to resist, and would have let them go to the butcher; but, if we are going to get a flock of sheep which will give us the result which this flock gave him, I do not know of any way that we can get them except to raise them in this way. I 
have made an estimate of the expense. The grain as he has given it to me would amount to about $\$ 9$; hay, estimated at $6 \frac{1}{3}$ tons, at $\$ 10$ per ton, $\$ 63$; pasturing 21 sheep 28 weeks, at 5 cents each per week (which I think is a very liberal estimate), $\$ 29.40$; service of ram, $\$ 5.25$; making a total of $\$ 106.65$, which leaves a balance of receipts ahove expenses of $\$ 95.93$.

Question. He got about $\$ 1.75$ each for the wool?

Mr. Areny. Yes, sir; just ahout that.

The Cuamus. That proves just what I have heen trying to impress upon the farmers of Massachusetts for the last eight or ten years, with very poor success; that is, that any farmer who has a good flock of sheep and who knows how to treat them as Mr. Avery and the gentleman who has given the statement which has been read here do, with average good luck, may reasonably expect to get an income of twentyfive per cent of the investment.

Question. Is that a continuous income from the sheep, an income that comes every day?

The Charmax. It does not come every day.

Mr. Avery. It comes perhaps twice a year. I have a statement from another gentleman who raises what we term early lambs, or spring lambs, which are turned to market without ever being turned to grass. In this case the lambs were dropped in December and carried to market in March and April. Flock No. 2 numbered in $1890 \quad 17$ breeding ewes. The receipts from these 17 ewes were as follows:-

150 pounds wool, at 23 cents,

16 lambs, at $\$ 9.06$,

3 lambs, at \$र,

$\$ 34.50$

145.00

15.00

Total, .

$\$ 194.05$

I presume those three lambs which he kept came later, and were reserved to replenish his stock. I made an estimate of the expense of this flock also, as follows :-

$5_{\frac{1}{10}}$ tons of hay, at $\$ 10$ per ton, .

$\$ 51.00$

Grain for sheep, .

25.50

Grain for lambs, .

16.00

Pasturing 17 sheep 28 weeks, at 3 cents each, . . . . 14.28

Service of ram,

4.25

Total, .

$\$ 111.03$

Balance of receipts above expenses, $\$ 83.47$. 
In this case there were no lambs to be pastured, and the ewes could he pastured for about one-half the cost of those that have lambs, as lambs must have the best of pasture. This flock of sheep was produced by crossing a spanish Merino ram upon grade Cotswold and Leicester ewes, and those ewes will weigh from 125 to 150 pounds. They drop their lambs very early, most of them in Decemler ; and they are ready for market early, and hing a hetter price than those which are dropled later.

Mr. Ware. It will he noticed, probably, that there has been no credit given for the mamme during this time, which is a fair item of eredit.

Mr. Arery. I have offiset the manure against the lahor, which is a very liberal allowance for the labor. I should be very glad to take a thousand sheep and take are of them for one-half the manure, if any one would furnish the hay and grain.

The Cunmux. You mean to he liberal in your estimates?

Mr. Arens. Yes, sir; I mean to be.

Questiox. I would like to ask Mr. Avery, if he increased his flock four or five fold, if he would get the same result as from a smaller flock?

Mr. Areny. Probably not. Sheep will do better in small flocks. I do not think the result would be as good with a large flock. I think it is usually considered in that light.

Flock No. 3 consisted of 53 ewes, 6 lambs and 1 ram, making 60 in all. The expenses were as follows :-

Grain for sheep and lambs,

$\$ 104.50$

Hay, estimated at $\$ 2$ per head, . . . . . . . . 120.00

Pasturing 60 sheep 28 weeks, at 3 cents, . . . . . 50.40

Service of ram, .

13.25

Total,

$\$ 288.15$

The owner of this flock gave me an estimate of the expenses. He said the grain which he fed to his sheep was kept separate, so that he knew just what his grain cost him which he fed to his sheep and lambs, and it amounted to the sum I have given. I will say that he also raises what we term early 
lambs. His receipts for lambs and wool sold amounted to $\$ 629.50$. He did not divide this up. for me. I had asked him in previous years what he was getting for his lambs, but he never seemed inclined to tell me, and he has not here. He gave, as the total receipts for lambs and wool, $\$ 629.50$, which you will see is almost $\$ 10.50$ per head. Balance of receipts above expenses, $\$ 341.35$.

These sheep are the Vermont Merino. They are a rery superior flock of sheep for that breed. They will weigh probably 100 or 110 pounds each, and probahly shear from eight to ten pounds of wool each. They drop their lambs in Norember and December. I saw the gentleman two weeks ago, and he had nine lambs at that time, and more coming right along. He has the advantage of the rest of us in marketing his lambs, or has taken the advantage, by selling his lambs dressed directly to the hotels in this city. He has a son here who has assisted in finding him a market, and I presume he gets one or two dollars a head more than the rest of us. I think he must.

Governor HoAnd. Is the sire a Merino also?

Mr. Arery. No, sir. In all the cases of which I have spoken, the sire is a pure-bred South Down.

The Champrax. Mr. Arery, won't you give us an account of your own flock, which is probably one of the best in the State?

Mr. Avery. No, sir ; I camnot show as good figures as these men.

The Chammax. These are all too good. You know people will not believe some of these stories.

Mr. Avery. Wrell, I have not prepared any figures from my own flock.

Secretary Sessioxs. How many do you keep?

Mr. Avery. I keep from 100 to 300.

Secretary Sessioxs. Your experience as far as you could give it would be very interesting, because your flock is a large one compared with those which you have mentioned.

Mr. Arery. I can tell you about what I get for my lambs, and ahout what I think it costs to raise them. The best that I have ever done in any year was some five or six years ago, when I raised 200 lambs from 180 ewes, and sold 
those lambs for $\$ 1,600$, and my wool averaged me about $\$ 1.50$ per head. But I estimate the expense of keeping sheep higher than most farmer's do. I have never weighed and kept an accurate account of the grain, but I think it costs me about $\$ 3$ per head for grain for the ewes and lambs, which is more than a dollar a head higher than this gentleman estimates of whom I have last spoken; but he says he does not know what the exact cost was. Perhaps he did not feed as much grain as I do.

The Cuamuas. Do you feed grain in summer?

Mr. Avery. No, sir.

Mr. (inswele. When does he turn his lambs? That makes a difference.

Mr. Avery. His lambs are dropped in November and December, nearly all of them, perhays some as late as danuary; and they are marketed in March and April mostly, some perhaps as late as May.

Hon. Jomx E. Ressell. Do you keep 300 sheep in one Hock?

Mr. Mreny. No, sir; I do not. In the winter my flock is divided "1 into pens of perhaps 2.5 , although perhaps 7.5 or 100 will be connected, with just a board fence, you might say, hetween them. The hay I estimate at s:3 per head and the grain at so per head for sheep which latise early lambs. I know that is a higher estimate than most farmers make, and perhaps it is too high. I have thought sometimesthat I would experiment in that direction, and weigh my hay and keep an accurate account of the grain; but it would be (puite an undertaking, especially to keep an account of the grain. where there is a mixed stock and the stock are all ferl firm one bin.

recretary sessioss. What is your estimate for pasturage?

Mr. Aveny. I have figmed the cost at :3 cents per work for 27 or 28 weeks, lut it does not actually cost me that. I hire pastures, and in that way I get them pastured for perhaps 2 cents a week sometimes.

Secretary SEsisoss. What is your pasture?

Mr. Arewr. It is an old pasture, hilly and rough.

(Questiox. Do you take any precantions against dogs? 
Mr. Avery. No, sir; I have not taken any precautions against dogs, and never have had any serious trouble. In some sections of our county some very valuable flocks have been entirely ruined by dogs. I have fortunately escaped anything of that sort.

There is one point to which the essayist alluded which I wish to emphasize, and that is, that the keeping of sheep requires constant care and attention. I think there is where many of us fail. We think that we can slight the sheep; that they ean get along almost any way, and shirk for themselves. That is not so. They require a certain amount of care. They do not require anywhere near as much care as a herd of cows, the labor is not nearly so much; but they should have just as good care as you give your cows. If you neglect your dairy cows for a day or two, the milk pail will tell the story; but it is not so with sheep; none but a practised eye will notice the difference. But, if you are raising early lambs especially, those lambs will very soon show any neglect, and if they are neglected for a short time they never will recover from it. There is no way to get along with them and raise them successfully but to give them good care and attention and good feed, and fit them for market as soon as possible. The sooner and the younger they can he prepared for market, the greater will be the profit. It costs less to fit lambs for market if you do it in eight or ten weeks than it does to be twelve or fourteen about it.

A. J. Buckin (of Adams). What is your method of housing in the winter? How large an extent of shed room do you require?

Mr. Avery. My sheep sheds are old-fashioned, as you might say. The sheds were built before I went on the farm, probably thirty or forty years ago, and they are not remarkably warm; but still, by fixing them up a little I make them warm enough, - as warm as I care to have them. I hardly ever lose a lamb in cold weather on account of getting chilled. As to the amount of space which they require, I have in one pen now, which is 26 feet square, 50 ewes, and I think that is perhaps as elose as they should be; perhaps more room would be better for them, but still they will do very well with that amount of room. After they drop their lambs and 
the lambs begin to eat, it will be necessary to give them more room.

Governor Hosnd. I would like to ask the gentleman how many mutton sheep can be kept safely in one flock?

Mr. Avery. Do you mean in the pasture, or in the barn?

Governor Hodrd. In the pasture first.

Mr. Avery. Well, the largest number I have kept as a rule is 75 or 80 .

Governor HosRo. How many in winter quarters?

Mr. Avery. The largest number which I have in one pen at the present time is 50 . I do not know but they might be kept in larger numbers safely, lut I do not think it is as well. If they are kept in small flocks it prevents their crowding.

The Cimammax. If $\mathrm{Mr}$. Avery will allow me, I have kept as many as 500 in one flock without any detriment, where there was plenty to eat in the pasture. In winter I should always divide them up into flocks of 30 or 40 , although I am at present keeping $175 \mathrm{in}$ one flock, and they do very well. You have got to use lots of common sense with sheep, besicles care.

Governor Hosrd. Have you had any experience in feeding ensilage to sheep?

Mr. Avery. I have not.

Mr. Havex. What breed are your sheep?

Mr. Avery. Mr sheep are grade south Downs.

Mr. Havex. Have you tried other breeds?

Mr. Aresy. I have tried the Merino, and had very tair strecess with them.

Governor Hosrd. In Wisconsin we have had quite disastrous results in feeding sheep when with lamb too heavily with ensilage. It being a carbonaceons food, it did not seem to give the proper growth. ('an you house mutton sheep closely with safety? And, in comnection with that matter of housing, I want to know whether you can secure thorough ventilation in your houses in winter?

Mr. Arery. Well, if they are homsed closely, it is very necessary and important that the pens should be rentilated in some way. There are very few days in the winter when some of the windows of my sheep pen are not open. 
Governor Hoard. Do you keep them constantly bedded, so that they shall not lie in filth?

Mr. Avery. I do, most certainly.

Governor Hoand. What do you use for bedding?

Mr. Avery. I use brakes, as a rule, which I mow in the pastures.

Governor Hoaro. How would you handle and feed a ewe when she lambs in December, for instance, and you want to prepare that lamh for early spring mutton?

Mr. Avery. I should feed her well from the time she went to the barn. I should want her to go into winter quarters in good condition; and, if I had plenty of fine early-cut hay and rowen, that would be all I would are for until after lambing. Soon after the lamb was dropped I should commence to feed a little grain, and the amount of grain would depend upon the quality of the hay. I have fed as high as a quart, - I have fed higher than that. I once fed a few ewes which had two lambs each, - I was fattening the ewes as well as the lambs for market, - I fed them over two quarts per day.

Governor HoARD. What kind of grain?

Mr. Avery. It was linseed meal, eotton-seed meal and provender, - corn and oats ground together and mixed in equal parts. It was more grain, I suppose, than most people would feed to sheep; lut it should be borne in mind that those were large ewes, and suckling two lambs each.

Question. Do you feed roots at all?

Mr. Avery. No, sir; I do not, although I think they are very excellent food for sheep.

Governor Hoard. Do you feed any peas?

Mr. Avery. No, sir; I do not. I have had no experience in growing peas.

Governor Hoard. Has any gentleman in the room had any experience in that direction? Several gentlemen in the West have been experimenting with peas for the past two years, with very remarkable success, both in dairy work and in sheep work, and we have learned some things that we did not know two, three or four years ago even. In planting field peas plough the ground in the fall, selecting not too rich soil. In the spring, as early as possible, paying no 
attention to early frosts, drag the ground thoroughly, sow the peas, and plough them under about four inches deep. After the peas are plonghed under, sow on the top from three pecks to a bushel of oats to an aere, to assist in holding up the peas. ('ut the (rol) when ready with an ordinary mower or reaper. We find that we can get from an acre of peas the equivalent in value of 4,500 pounds of bran.

Mr. Griscele. I want to say that some two or three weeks ago I prepared some circulars containing about a dozen questions, and sent them around to various gentemen represented to me as heing sheep raisers. I sent them out hy the hundred. I have received over sixty replies to those circulars. They contain a great deal of rery interesting matter, which, if tabulated, would emhrace all that has been said to you in regard to the keeping of sheep, - the cost, the profit, and so on.

The Cindruax. Well, gentlemen, we are gathering a good deal of information about the raising of sheep; but there is one thing which we want to learn a little something alsout, and that is about our old Arab friend. We have an old friend of the Board here who knows more or less abont the tariff. I should like to hear from the Hon. Jonx E. Rissell.

Hon. Johr F. Ressell (of Leicester). Mr. Chairman, Memhers of the Board, and Gentlemen: It is eleven years last Angust since I was elected Secretary of the Board of Agriculture, and during that year I said several times in publie, that if at the end of five years 1 had not increased the sheep in the Commonwealth of Massachusetts by my advocacy of sheep husbandry to the number of half a million, I should feel that I had been secretary in vain. After six or seven years I retired from the office, and there were alout half or two-thirds as many sheep in the Commonwealth as when I began to adrocate sheep husbandry. Otherwise perhaps I was of service to the ('ommonwealth in my position; I flatter myself that I was, hut I did not inerease the interest of the firmers of the state of Massachusetts in sheep hushandry. We had very animated meetings and institutes all over the Commonwealth, but I notice that there has been - one very great step of progress taken. This is the first pulb- 
lic meeting that I have ever attended in which this question was discussed, that the whole matter was not met at the outset by the ery, "We cannot keep sheep on account of dogs." We have not heard that here to-day, and I take it that the farmers of Massachusetts have got to the point where they consider that they can keep sheep if they choose to do so, dogs or no dogs. They have also made up their minds that they cannot prevail any further with the Legislature of Massachusetts than we went during my term as secretary, when we had the law very largely amended in our favor; and we now have as farorable a law on our side in this Commonwealth as we can expect to have, or, I may say, as we are entitled to have.

I am glad to talk upon the sheep question; but I do not propose to discuss our old Arab friend particularly, because I do not recognize that the tariff upon wool has much to do with the sheep hushandry of Massachusetts. We do not raise wool enough to make it at all important to us what the tariff is. I once said, amid the jeers of a good many men who ought to have known better, that the farmers in the States west of the Mississippi River, I stated it on the floor of the House of Representatives, and it is in the congressional record, - that the farmers west of the Mississippi River could afford to keep sheep if wool was worth no more than hen feathers. Having said that there, I can say here that it is immaterial what the tariff is. I might add to that, as a sort of snapper, that when wool was free in 1859 it was worth more money in all parts of the United States, considering the value of money at that time, than it had ever been before, and worth more money than it has been since 1867 under a high tariff. The secretary says, "or ever will be in the future." That may be, too. I am glad to get a good price for my wool, of course; but I do not reckon the wool as an absolute necessity of my sheep keeping. I should keep my sheep first for lambs, second for mutton, next for the improvement of my pastures and the manure that I could get ont of the sheds; then if I get $\$ 125$ or $\$ 150$ for my wool, that is so much addition to my profits. I agree with the gentlemen who have spoken here who have kept sheep, as I have, for some years, that there is a constant annual profit; not a daily 
profit, as one gentleman here wanted to get, although I have known cases where sheep raisers got a daily protit by marketing the ewes' milk; hut I do not think we need to do that in Massachusetts to make a profit. But the annual profit of the sheep is, we might almost say, an absolnte certainty. I told a pool farmer within two or three months, that, if he had my flock, which has never exceeded 75 or 80 , he could stuport his fimily, pay his taxes and hold a respectalile position as a farmer. with nothing more than that Hock, a garden, and what he could do on 25 acres of land.

Mr. SIIw. I want to ask if your sheep in the winter have exercise, or are they kept in a pen all the time?

The Cuamiax. I have found from experience that with sheds as close as I have, allowing alout 10 square feet to a sheep, and dividing them up into flocks of 50 or 60 , they need a small yard for exercise. The larger the yard we can have, and keep) it dry, the better.

Qunstox. Has anybody ever tried soiling sheep as we soil cattle?

The cummux. I do not know whether any other gentleman has done that or not. I have tried it in a very small flock myself:

Governor Hoaro. That is the English practice. All the flocks of England are soiled. That is, they have a small run of pasture, and generally a movable fence is used. They plant green erops and let the sheep feed on them, moring their hurdles four feet in the morning and at noon, and eight feet at night, and thus make the shecp eat everything jerfectly clean. In that way they feed on the green crop and manure the field as they go along, and then the land is ploughed over and sowed with another ('rop.

The Comanax. I am not aware that that has been tried in this comntry, except in an experimental way. I think it has been tried at Amherst with English rape.

Gorernor Hosnd. There are some surprising results given by Professol shaw at Ontario College. We have commenced to try it in Wiseonsin, so far with very flattering results. Professor Shaw makes the bold statement that there will be within a compuratively fow years ten million sheep fattened in this country on rape, and he gives figures, 
which unfortunately I have not with me, which show very surprising results from the sheep fed on rape; and the growth that he made upon lambs and sheep from New Brunswick and the easter'n Province of Ontario almost passes belief; but the figures are given with the assurance that they are absolutely correct.

The Chammax. Will Colonel Needham kindly give us some account of his dealings with sheep in former years? I think he took a celebrated flock across the water.

Hon. Daxiel Needhan (of Groton). I will occupy a brief moment. This is a sulpject which has always been of great interest to me. I had something of a flock of sheep in Vermont for quite a number of years. I had the old Consul Jarvis sheep, which he sent to this country as early as 1810 or 1811. The loucks were sold in New York at that time for about $\$ 1,000$ apiece; the ewes brought from $\$ 100$ to $\$ 150$ and $\$ 200$. The sheep which I took to Europe, to which Mr. Grimncll alluded in his address this morning, were the Spanish Merino; that is, they were the descendants of the sheep which were imported by Consul .Jarvis. Mr. George Camplell of V $r$ ermont had travelled with American breeders throughout Europe on two different occasions previous to 1863 , when those sheep were exhilited at the Hamburg International Exhibition; and he was satisfied that it did not belong to Germany that she should have the exclusive right to claim the production of blooded Merino sheep; that as good sheep could be found in the United States as could be found there; and he was confident that he had as good sheep on his farm ats he saw in Spain, in Saxony or Germany. In 1863 , as very likely many of you may remember, I was appointed a commissioner from Vermont to go to the International Exhibition at Hamburg, to which the United States was invited to send sheep. The great interest of Vermont in that exhibition was in connection with the breeding of sheep, and George Camplell was the only man in Vermont or in the United States who dared to venture on the sending of Merino sheep to that exhibition. He sent twelve, and I went over in the same ship that carried the sheep and the shepherd, and in which Mr. Campbell was also a passenger. I remember that there 
was a German baron on board the ship, who went to $\mathrm{Mr}$. Camphell and said, "I understand you have some Merino sheep that you are going to take to Germany to compete with German Merinos?" Mr. (amphell said "Yes;" and he said, "Well, it is the old story of currying coals to Newcastle," - and we almost felt that it was so. The sheep reached Hamburg all right, though they had been a little seasick on the passage, hut they had eaten reasonably well. They had been well fed with oats and heans. We always fed our sheep with beans in Vermont, as one of the hest means of producing a good heary fleece of wool. Those sheep were made the suljeet of very general discussion in the newspapers. Mr. Charles L. Flint, who was the predecessor of Mr. Russell, in the office of secretary of the Board of Agriculture, was also a commissioner to that exhibition for the state of Massachusetts. Grovernor Wright of Indiana was the commissioner from his State and from the United States, appointed by President Lincoln; and Rhode Island and other States had commissioners there. When our sheep got there they immediately began to be the butt of riclicule of the German press, and they took up the story of the baron, that it was " carying coals to Neweastle;" that the United States - they did not know anything about Vermont - had sent sheej over to Europe to compete with the Spanish Merinos of Germany. Germany had had almost full sway in the production of stock Merino sheep for more than thirty-tive years, - ever since - jain gave it up. We nevertheless went to work, put our sheep into pens, and entered them in the various classes. There were some three hundred Merinos at the exhibition. The judges of the exhibition were men who knew nothing ahout the owners of the sheep, except so fur as they were obliged to know. They were obliged to know that there was only one lot of sheep sent over firom the United States, and so far as they had to know they knew of the owner; but when those sheep passed under the inspection and study of the judges it seemed to me that they were unprejudiced. They were ealled "Vermont Merinos," but I venture to say that there were not fifty men on those grounds, which sometimes contained 
one hundred thousand people, who knew where Vermont was. They had an idea that it was somewhere over here in this western hemisphere, but where they did not know. The judges went around and made their decisions, and when they came to compare notes they gare those Vermont Merinos two first premiums and one second prenium. The excitement on the ground was intense. No language that I can command could depict the excitement among the German and French breeders. Lonis Napoleon himself, then the Emperor of France, had on exhibition right by the side of those Vermont pens, in a highly decorated pen built by himself, sheep competing with those Vermont sheep; and there were distinguished breeders from rarious countries of Europe, and some from South America. The decision was, of course, very acceptable to the American conmissioners. Governor Wright came to me and said: "A great victory has heen won for our country; it will result in a change of the current of trade in stock Merinos. Our people have heretofore sent to Germany for their stock sheep, but now they will send to Vermont, - the American people will find their stock sheep at home." And they did.

But I must tell you a little more ahout this exeitement. The German and French hreeders did not believe that the decision could be honest; and yet the men who constituted the judges were largely Europeans; they were of all nationalities. The excitement, as I said, was very great, and Governor Wright said to me, "I don't know but they will mob you and Mr. Camphell," so wrought up were the breeders who were exhibiting on the grounds. They did not believe that anything good could come ont of America. I made up my mind that there was one test which could be applied. These sheep were not sheared. One of the first prizes which was awarded to us was upon the weight of fleece in comparison with the weight of borly. That could be tested, and I offered 100 thalers, which is $\$ 70$, for the sheep that would shear the heaviest fleece for the weight of hody in the class of Merinos, the sheep to be sheared and the fleece to be weighed in the presence of a new jury appointed by the German league 
and in the presence of the whole public. I had that notice printed in French, in German and in English, and put up on every pen on the great exhibition grounds, and three days were given for the entries. When the third day had expired no entries had been made except by (reorge (amploll of the United States of America. Then the German press turned round and said, "The American gentlemen have vindieated their integrity, and the exhibitors and hreeders of the European sheep on exhibition here have not dared to enter." After the exhibition Mr. ('mmplell came home, and fovernor smith of Vermont in his next message said that the result had been worth a hundred thousand dollars to the state of Vermont; and he told me afterwards that he might just as well have put in his message that it was worth a million of dollars to the state of Vermont. Vermont sent sheep to Australia, to Texas and all over the United States, where the leading breeders had been in the habit of sending to Germany; and the whole trade in stock Merinos was changed from that great entrepot of Spanish Merinos, Germany, to the United States.

secretary sessioss. I do not believe that this discussion can be fitly closed without a leaf from your own experience, Mr. ('hairman. I helieve you have the largest flock of sheep of any man in Massachusetts, and I am sure the audience would all like to hear from you.

The Cunmux. Well, gentlemen, I should be very glad to give you the result of my experience, hut I think most of you have heard the oft-told tale. I should eorroborate a good deal that Mr. Avery has said. One question that was asked was about ventilation. The principal rules of successful sheep husbandry are, that the sheep must be kept eool and dry, and have enough to eat. That is the whole secret of sheep hushandry. "And rumning water" is suggested by the essayist, which goes without saying. On that sul)ject of water, I think few people will believe the amount of water that a hundred-pound ewe with a lamb by her side will drink. I unfortunately was dependent for water for a flock of some three or fom hundred ewes on a windmill ; the wind didn't blow for tive or six days, the thermometer went down below zero, and it was a very difficult joh to hanl water for 
those sheep. I had one or two ewes with lambs by their side in a small pen, and $I$ found that, on the arerage, the $y$ would drink between five and six quarts of water a day.

With regard to keeping mutton sheep, there has always been an idea, I think, in this part of the country, that it was only the Merino that would stand running in large flocks, and when I first began I was told that I could not keep more than twenty or thirty together; but I gradually increased until I have kept a flock as large as four hundred together in a summer pasture, feeding them grain. To topdress my pasture and kill the underorowth, I kept the pasture overstocked. I have kept them from early in May until Octoher on the same feeding ground, the same flock together, and with no more disease than you would naturally expect from hurdling as I do at night. I have adopted that plan with pastures which were becoming run out, grown up to bushes and covered with moss. I hurdle my sheep at night for two reasons. One is to top-dress the part of the pasture which needs it most, and, secondly, as furnishing protection against dogs. I never have had a $\operatorname{dog}$ jump over a hurdle.

Questiox. What do you build your hurdle with?

The Cuarruax. Merely take an eight-foot section of an ordinary pieket fence, and two inches from the end of the two-by-three stick to which your pickets are nailed bore a hole, then put your sections together like an old Virginia rail fence, and where the holes come above one another put in a piece of bent iron or a fire-inch spike, and your fence is very strong and very easily moved.

Mr. Avery also said that sheep needed constant care, and they do. The labor is very light. There is very little hard labor in looking after sheep ; but it is that very looking after, the master's eye, that covers what is ealled generally "good luck." There is no such thing as good luck. It is good eare ; and in no branch of farming that I know of does good care go further than in looking after a flock of sheep. One trouble that I have had in hurdling as closely as I do, three or four hundred in a small hurdle, is that they get very foul in the feet, and are apt to get foot-rot. The master's eye, if he exercises good care, sees when they are let ont of the hurdles in the morning that there is a sheep or lamb affected 
in that way, and when they are hurdled again at night that sheep or lamb must be removed, and the disease not allowed to get into the contagious state. In that way it can be checked rery easily.

\section{QLenton. How?}

The Cunnux. There are varions prescriptions in the books. Onr former secretary's sheep dip is first-rate for foot-rot. If too strong it will take the skin off of a man: arm, but if it is put on of the proper strength it will cure the foot-rot. Then there is the prescription of rerdigris and carbolic soap in the old books.

I should disagree with Mr. Avery, if he will pardon me, with regard to the expense of keeping sheep. I think he has got it too high, particularly in the item of hay ; hecause I have found by actual experience that the highest-priced hay, that is, the best puality of hay, is not so eagerly sought after by sheep) as a poorer quality. I have tried that experiment hy using a stack of very poor meadow hay, so poor it was hardly worth putting in the barn. I found that when my sheep had hecome used to it, say after feeding it two or three days, they would leave early-cut rowen and hunt uj, those old brakes. Of comse, to keep them in condition and to keep a flow of milk for the lambs, that feed must be sup)plemented with a grain ration. And another thing that reduces the expense of keeping a sheep for the whole saran is, that, where ten rears ago it nsed to take alont three months, more or lexis, to get a lamb ready for market, now, ly using a sire of one of the improved I)own hreeds, with a good crade ewe, well fed, you can as often market a lamb under fifty days as we used to do it in a hundred days.

Mr. Grixseld. What age or size lamb do you find the most marketable?

The Cumbus. Our local market in Boston is not atetive for lambs until into February. There may be ocrasionally one asked for before that, but as an ordinary rule the market for lambs does not open until into February, and at that time lambs will he taken weighing from twenty-fire to twentyeight pounds, which, bred firom improved sires on goorl grade ewes, ought to be put into the market at six weoks' old. 
S. E. Stone. I would like to ask one question in regard to pasturing sheep. Is it desirable or proper to keep sheep continually on the same pasture?

The Chairman. They do better to change. I merely stated that as an exaggerated system. I have tried that, and tested it very carefully. I propose to cut my pastures up into five or six, and let the sheep run ten days in one and ten days in another.

Question. How many sheep can you feed on one acre, as compared with one cow?

The Chairman. From eight to ten.

Hon. J. E. Russell. You might have stated that the buyers in Boston want lighter lambs than they used to. They will buy lambs weighing from twenty-two to twentyfive pounds, when they used to insist upon having a lamb weigh thirty or thirty-five pounds.

The Chairman. When I began it took me from seventy to eighty days to get lambs that would dress twenty-five pounds. I can now do it easily in forty days. 


